\title{
PENCERMATAN PARADIGMA NILAI-NILAI LUHUR ISLAMI Dalam Tata Hidup Bermasyarakat Dan Bernegara
}

\author{
Oleh Achmad Mudlor
}

Penulis adalah Dosen Tetap STAIN Malang dan Dewan Kiai STAIN Malang

\section{Pengantar}

Pencermatan paradigma berarti pencermatan sistem dan susunan yang terkait di clalamnya. Scope nilai-nilai luhur dalam sorotan Islam juga sangat luas dan mendalam yang terbentangkan clalam buku-buku otentik salafialh, khususnyal buku-buku yang membahas akhlaq dan tasawuf. Dalam makalah ini hanya menyoroti garis-garis besarnya sajja.

Nilai-nilai Istam padal garis besarnya terkait pada jalur bablun-minallab sebagai jalur vertikal dan bablin-minannas sebagai jalur horizontal. Antara keduanyal tidak clapat terpisahkan dalam susunan mayarakat (society). Dalam menciptakan keadilan dan kemakmuran, keclua garis tersebut harus berjalan secara integral, harmonis, clan koheren. Banyak sekali nilai-

Apabila kedua elemen dasar yang terkandung dalam dua bablun (tali hubuingan) berjalan atau berproses secara integral, harmonis, dan consequent, maka terciptalah response dari challinge terhadap kondisi yang merugikan perikemanusiaan (bumanity) dan perikesusilaan (morality) seluruhnya (AIAshr : 13). nilai luhur yang terkandung clalam clua jalur (hablu) itu tetapi masing-masing terdapat nilai clasar yang menentukan keluhuran nilai-nilai lainnyal.

Setiap individu mempunyai bermacammacam kebutuhan, sering sekali kebutuhankebutuhan itu searah dan sepadan tetapi kadlang-kadang bertentangan atau berlainan sehingga terjadi bermacam-macam kejahatan moral clan krisis sosial, bahkan terjadi perkelahian dan peperangan sebagian ucapan Hobbes: "Bellum ommin!n contra omnes". Tetapi apabila nilai-nilai luhur dalam kedua hablun diamalkan di tengah kehiclupan masyarakat secara consequent maka clapat cliharapkan terciptanya masyarakat adil dan makmur cliridloi oleh Allah.

Nabi Muhammad S.A.W. dengan misinya menciptakan akblaq karimab telah berhasil merealisir clua hablun itu clalam tatanar politik, ekonomi, sosial dan lain-lainnya, sehingga terciptalah negaral (Madinatun Nabi) adil clan makmur tanpa mengerahkan kekuatan politik dan kekuasalan militer. Dalam waktu yang relatif singkat clapat membebaskan masyarakat dari krisis politik, ekonomi, hukum clan sosial.

\section{Paradigma Nilai-nilai Luhur Islami Dalam Bermasyarakat dan Bernegara}

Dua elemen clasar yang mutlak (Something bas to be done) harus terwujud clalam tata hidup masyarakalt manapun, termasuk mayarakat Indonesia. Untuk mewujudkan keadlilan dan kemakmuran, maka elemen dasar yang terkandung clalam bamblinn yang pertama clan elemen dasar yang terkanclung clalam bablun yang kedua, masing-masing adalah iman dan amal sholeh.

Apabila kedua elemen dasar yang terkandung clalam dua bablun (tali hubungan) berjalan atau berproses secara integral, harmo- 
nis, dan consequent, maka terciptalah response dari challinge terhadap kondisi yang merugikan perikemanusiaan (bumanity) dan perikesusilaan (morality) seluruhnyal (Al-'Ashr : 1-3).

Krisis semacam kondisi tersebut akibat manusia tidak merealisir teori di atas dan hanyal merealisasi sebagian kebutuhan material masyarakat tanpa ada integral rasional dengan kebutuhan spiritual. Hal ini sebab terjadinya berbagai krisis, sehingga terjadi exploitasi manusia terhadap manusia, kejahatan moral, kesenjangan sosial dan sebagainya.

Untuk mengantisipasi situai tersebut maka perlu diterapkan ajaran bablun minallab yang mengandung nilai dasar iman kepada Allah dan bablun minannas yang mengandung nilai dasar amal sholeh, dimana hablun yang pertama sebagai asas dan dasar bablun yang kedua. Merealisasi bablin yang kedua dikendalikan oleh asas dan dasar tersebut. Pengetrapan kedua elemen clasar tersebut harus clitopang oleh elemen clasar yang ketiga, yaitu akhlaq karimah. Akhlaq karimah merupakan perekat kuat terhadap harmonisassi antalaa lapangan politik, ekonomi, sosial, hukum, seni dan sebagainya.

Negara pada hakekatnya hanya kelompok masyarakat yang besar yang cliatur secara formal dan serba meliputi (Inclusive society), sedangkan rumah tangga adalah kelompok masyarakat terkecil dalam struktur masyarakat. Di antara keduanya ada bermacam-macam kelompok denga dasar dan tujuan yang berbeda-beda. Dalam pengetahuan sosiologi solidaritas kelompok yang kecil dalam berbagai kepentingan lebih kuat dari pada kelompok yang lebih besar dan seterusnya. Disinilah letak rahasia kewajiban keluarga untuk menatar akhlaq karimah sjak lahimya anggota baru yaitu bayi (Lucpman : 13 - 19) dengan harapan dapat melakukan adaptasi, tenggang rasa, pengendalian diri sertal rasal ikut bertanggung jawab apabila kelak hidup clalam masyarakat yang lebih luas.

Karena watak stiap golongan lebih fanatik dengan golongannya sendiri (Ar-Rum : 32), maka betapa sulitnya menuntut masyarakat untuk berkarya dengan mengutamakan kepentingan negara di atas kepentingan golongan. Untuk mengantisipasi kesulitan ini ajaran Islam memberi solusi bahwa filsafat tujuan umum hukum dan syariat Islam yaitu membuka pintu rahmat kepada umat dengan nilai-nilai luhur (Masholibul 'Ammab). Nilai-nilai ini meminta untuk diterapkan pada smua asspek kehidupan manusia. Tidak hanya di ssatu negara, akan tetapi secara global meliputi seluruh bangssa-banga di dunia. Ajaran ini jugal diakui oleh Prof. Dr. S. Hourgronye, bahwal "Mubammad's religion takes the principle of the equality of all buman races".

Nilai dasar iman kepada Allah merupakan elemen pokok dalam bablun minallab. Konsekuensi iman ini berarti terwujudnya keclaulatan Ilahi. Realisasi kedaulatan itu berbentuk hukum atau peraturan yang bebas clari pengaruh subyek dan obyek hukum. Hukum atau peraturan yang bebas clari interes pribadli atau golongan. Dengan demikian tidak ada seorangpun, baik secara kolektif berbentuk organisassi maupun secara individu berbentuk raja atau presiden berhak memiliki kekuasaian trtinggi. Seluruh anggota mayarakat memiliki hak dan kewajiban yang sama di muka hukum tanpa terkecuali. Nilai luhur ini yaitu persamaan hak dan kewajiban. Nilai ini pun makin kuat dan menjadi keyakinan umat manusia hinggal era globalisasi clewala ini. Ajaran nilai ini dapat dicermati dari ucapan Sayyidina Umar ral. "Waqad waladatbum ummabatuhum abrara". Dan diperkuat oleh ucapan filosof Barat (John Lock): "Men are created free and equal".

Bagi kelompok yang besar seperti negara yang ground norm (norma asasi)-nya Ketuhanan 
Yang Maha Esa, maka konskuensi logisnya segala hukum, undang-undang dan peraturan tidak clibenarkan apabila bertentangan clengan ajaran Ilahi. Sekalipun demikian clalam menetapkan unclang-undang atau peraturan harus tetap memperhitungkan realitas yang berlaku dalam pergaulan hiclup masyarakat. Pandangan ahli-ahli sosiologi hukum modern, jauh sebelumnya telah dipraktekkan oleh Sayyidina Umar ra pada waktu menjadi Amirul Mukminin, Beliau pernah menghapus dalam waktu tertentu tentang hukuman potong tangan bagi pencuri dan diganti hukuman yang lebih ringan. Di sinilah bagi masyarakat yang menjaclikan agama sebagai unsur penting memerlukan lembaga khusus yang personalianya dari ahli-ahli agama untuk mencleteksi atau meneliti apakal sudah patut untuk diberlakukan.

Hikmah

yang tersembunyi clalam jenis-jenis ibadah menunjukkan kesatuan manusia, baik materiil maupun spirituil.

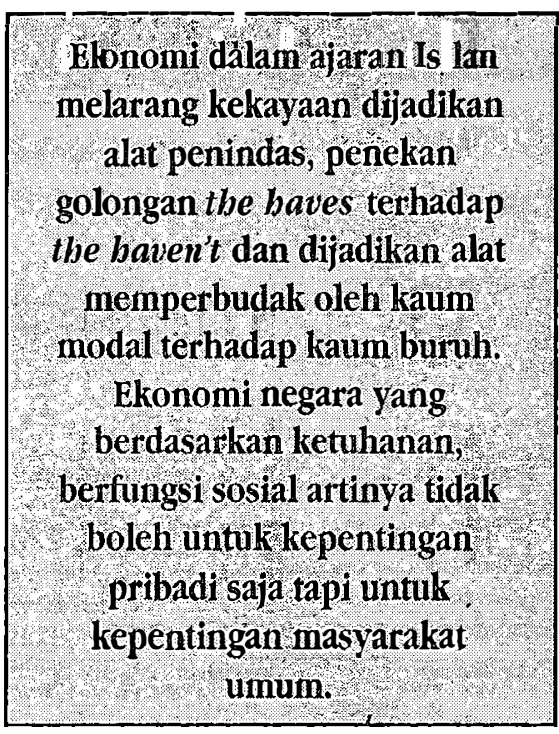

akblaq-akblaq mabmudah.

\section{Faktor yang Berperan dalam Tata Nilai}

Faktor yang pertama yang berperan dalam tata nilai Islam adalah faktor ekonomi. Islam mengakui hak milik perorangan, tapi cli balik itu membebaskan manusia clari perbuclakan harta. Ekonomi clạlam ajaran Islam melarang kekayaan dijadikan alat penindas, penekan golongan the baves terhadap the baven't dan dijadikan alat memperbudak oleh kaum modal terhadap kaum buruh. Ekonomi negara yang berdasarkan ketuhanan, berfungsi sosial artinya tidak boleh untuk kepentingan pribadi saja tapi untuk kepentingan masyarakat umum.

Hak milik berfungsi sosial terlihat pada ajaran Islam, misalnya nafaqab tidak pada keluarganya sendiri tetapi juga untuk pengurus tempat peribadatan, keluarga kampung dan pengurus tempat-tempat sosial di manapun mereka berada. Zakat clan puluhan macam Nilai-nilai sosial penuh tersimpul clalam ibadah shalat, zakat, puasa, haji clan lain-lainnya, Iman, amal sholeh dan akhlak karimah tergambarkan secara implisit maupun eksplisit. Amaliah wajib tersebut clilakukan secara kontinyu selama bertahun-tahun sehinggal mampu membertuk mayarakat yang dapat clijamin clalam bidang solidaritas sosial, kohesi, sosial, kesetiakawanan sosial, keamanan sosial dan jaminan sosial. Amaliah wajjib tersebut dapat berpengaruh positif terliadap terwujudnya tigal nilai daar yang harmonis sebagai landasan arah hiclup masyarakat yang adil dan makmur. Pada gilirannya akan diikuti clengan berbagai deretan shadaqab wajib clikeluarkan untuk menolong fuqara' dan masakin. Bahkan orang yang beriman sebenarnya wajib mengorbankan hartanya dan dirinya untuk kepentingan masyarakat.

Ajaran Islam sepanjang zaman mèmpunyai komitmen terhaclap kesenjangan sosial, memberantas kemiskinan clan memberantas oknum-oknum yang memperalat politik guna kepentingan ekonomi mereka. Undlang-undang clan peraturan tentang ekonomi pacla suatu masyarakat ticlak akan berhasil apabila pemegang perekonomian memperalat ekonomi 
untuk keperluan rafsu serakahnya. Faktor inilah yang menyebabkan terjadinya krisis ekonomi dan mempengaruhi sektor-sektor lain.

Faktor kedua yang berperan dalam merealisasi tata kehidupan masyarakat yaitu tindakan rasional. Ajaran Islam tidak menutup perkembangan rasio. Bagi Islam massalah berfikir dan kebebasannya serta pengembangannya adalah proses yang tetap ada bersama adanya manussia. Sudah barang tentu pengertian kebebasan berfikir dalam tata sosial masyarakat tidak membebaskan diri pada setiap ikatan dan tanggung jawab di tengah-tengah masyarakat, karena sikap yang demikian itu berarti menjadikan manusia lain tidak bebas dan menjadikan dirinya terikat dengan nafsunya.

Karena manusia adalah makhluk yang aktif berfikir, maka dalam kelompok masyarakat yang besar seperti negara, semua aturan-aturan dalam kelompok tersbut harus logis dan tidak bertentangan dengan pemikiran-pemikiran yang rasional, agar tidak terjadi kontradiksi statemen (pernyataan) dan manuver̀ yang tidak berakhir. Kbebasan berfikir harus disertai dengan kebebasan menyatakan hasil fikirannya. Dalam ajaran Islam berfikir dan menyatakan hasil fikirannya termasuk kreatiitas spiritual yang penting bagi kemajuan umat. Bagi kelompok yang besar seperti negara maka menyalurkan hasil pikiran yang bermanfaat disalurkan melalui lembaga-lembaga yang disediakan yang representatif dipilih langsung oleh rakyat secara adil, seperti ablul balli wal 'aqdi. Apabila wakilwakil rakyat tidak berfungsi, maka diijinkan untuk amar ma'ruf nahi munkar pada para pemimpin masyarakat. Ada empat alternatif hukum dalam melakukan amar ma'ruf nabi munkar yaitu :

1. Apabila yakin amar ma'rufnya tidak diterima dan berakibat mendapat bencana maka tidak wajib. Yang bersangkutan cukup diam dan tidak berpartisipasi;
2. Apabila yakin amar ma'rufnya berpengaruh, artinya kemunkaran dapat dilenyapkan dan tidak ada bencana apapun yang menimpa, maka kondisi ini wajib dilaksanakan.

3. Apabila yakin amar ma' rufnya tidak diterima dan tidak ada bencana apapun terhadap dirinya, maka hukumnya sunat.

4. Apabila yakin amar ma'rufnya mampu melenyapkan kemunkaran, tetapi yakin akan ditimpa bencana, maka kondisi ini tidak dilarang.

Untuk menyalurkan kekebasan berfikir dalam masyarakat daerah, cukup dilakukan musyawarah (Ali Imron : 159). Untuk penyaluran tersebut syarat mutlak adanya organisasi yang demokratis sbagaimana yang telah dipraktekkan oleh Abdullah bin Umar dan ulama-ulama dahulu kala hingga dewasa ini.

Faktor-faktor lain yang berperan dalam merealiasi norma-norma luhur pada tatanan kehidupan masyarakat banyak sekali, tergantung dengan kondisi yang hidup di tengah-tengah mayarakat itu. Kondisi tersebut selalu berubahubah dan berkembang seperti ilmu pengetahuan, selalu in the making, tidak pernah berakhir dan slesai. Di sini diperlukan pemimpin-pemimpin masyarakat dan negara yang handal, baik eksistensinya, kapabilitasnya maupun profesionalismenya dan loyalitasnya. Disamping mampu mengkondisi kaedah-kaedah hukum di tengah-tengah situasi yang dialektis.

\section{DAFTAR PUSTAKA}

1. Al-Qur'an dan Hadits;

2. Syeh Ali Ibnu Umar, Addin wal Jamaáb;

3. Prof. Ir. SW. Tromp, The Religion of The Modern Scientist;

4. M. Farid Wajdhi Chalid, Al Islam DinulIslam;

5. Mustofa Al-Gholayani, Al-Islam Rubul Madinab;

6. Al-Ghazali, Fiqbus Sirob. 